Man and Nature

MAN AND NATURE

L'homme et la nature

\title{
The Rights of the Individual in Habsburg Civil Law: Joseph II and the Illegitimate
}

\section{Miriam J. Levy}

Volume 10, 1991

URI : https://id.erudit.org/iderudit/1012627ar

DOI : https://doi.org/10.7202/1012627ar

Aller au sommaire du numéro

Éditeur(s)

Canadian Society for Eighteenth-Century Studies / Société canadienne d'étude du dix-huitième siècle

ISSN

0824-3298 (imprimé)

1927-8810 (numérique)

Découvrir la revue

Citer cet article

Levy, M. J. (1991). The Rights of the Individual in Habsburg Civil Law: Joseph II and the Illegitimate. Man and Nature / L'homme et la nature, 10, 105-112.

https://doi.org/10.7202/1012627ar

Copyright (C) Canadian Society for Eighteenth-Century Studies / Sociéte canadienne d'étude du dix-huitième siècle, 1991
Ce document est protégé par la loi sur le droit d'auteur. L'utilisation des services d’Érudit (y compris la reproduction) est assujettie à sa politique d'utilisation que vous pouvez consulter en ligne.

https://apropos.erudit.org/fr/usagers/politique-dutilisation/ 


\section{The Rights of the Individual in Habsburg Civil Law: Joseph II and the Illegitimate}

Emperor Joseph II, who ruled the Habsburg lands as sole ruler from 1780 to 1790, was one of the most enlightened absolutists of the eighteenth century. His Toleration Patent, his attempt to have a single tax which all his subjects would pay (the nobility included), his limitations on the Catholic church's activities in his lands and provinces, and his abolition of Leibeigenschaft (the hereditary binding of serfs to the soil) are some of his most widely known reforms.

Less well known is Joseph's General Civil Code of 1786, eclipsed in its reputation by Francis II's full Civil Code of 1811. Joseph decided that he would enact sections as they were completed rather than wait for a full code to be drafted. Joseph's 1786 code was therefore the first part of an intended code, and was also the first set of laws to apply to all Habsburg territories except Hungary, Lombardy, and the Austrian Netherlands. The 1786 code was very much concerned with the rights of his subjects, including those with very limited rights - the illegitimately born.

From ancient times through the Middle Ages, into the 1786 Austrian Code, and well beyond, there were different categories of illegitimately born. In the Middle Ages in most Germanic territories, the illegitimate had no rights of any kind, except for an occasional local inheritance claim on the mother's property. People born out of wedlock also suffered the stigma of illegitimacy, which prevented them from holding public offices of any kind at any level, entering a trade, joining a guild, or leaving a will to dispose of their own property.

While each of the Habsburgs' lands had it own laws and traditions, most of them began gradually to ease the restrictions on the illegitimate in the late Middle Ages - some in one way, some in another. Most laws assumed that the father was known and acknowledged. The medieval Vienna City Code (Art. 91 and 92), said that children born out of wedlock might have a claim on the father's estate if he had no legitimate heirs (children, siblings, nieces or nephews). The illegitimate could be legitimized by their father and would then have the same rights as legitimate 
children. These late medieval laws also spoke of 'untimely children,' that is, those born too soon after the wedding or too late after the father's death or departure. Such untimely children had no inheritance right vis-a-vis the father or the mother. ${ }^{1}$

By the 16th and 17th centuries in Austria, the position of the illegitimate continued to improve gradually. As a rule, while illegitimate children still had no inheritance claim on their father's property, they did have (or acquire) one on their mother's if she was not a noble or 'illustrious person' and had no legitimate children. Otherwise, illegitimate children could claim only necessary support and a dowry corresponding to the mother's property. ${ }^{2}$

Another category recognized by law was children born ex coitu damnato (of forbidden unions), that is, as a result of incest or adultery. In Austria below the Enns in a 1595 code, these children could inherit fully from the mother or maternal relatives only if there were no legitimate children. If both legitimate and illegitimate children were present, then the illegitimate's share was only half that of the legitimate children. ${ }^{3}$

The illegitimate were also limited in their right to make a will disposing of their own property. In many regions, they could do so only if the ruler granted them a special privilege. And in some areas their father could not name them as heirs, even if he wanted to, but could provide only for a dowry and support unless, again, the ruler granted a special privilege. ${ }^{4}$

Early in the 18th century, Charles VI (1711-1740) issued his New Ordinance on Intestate Inheritance, issued for each of the German hereditary lands individually and with slight variations beginning in 1720; his daughter and successor issued the last one in 1747. This statute also divided the illegitimate into those born ex coitu damnato and those whose parents could have married at the time of conception. Those conceived from forbidden unions had no intestate or statutory inheritance right toward either parent nor could they inherit from parents or siblings, but they were entitled to claim necessary support. At their death their own property did not go to their children or relatives (if they had any) but was treated as heirless and went to the treasury. Other illegitimately born, whose parents could have married, were entitled to inherit from the mother if she was not a noble and had no legitimate children. But this second group of illegitimate could make no claims on the father's legacy, nor he on theirs. ${ }^{5}$

In mid-eighteenth century Joseph's mother, Maria Theresa (17401780), began the drafting of new criminal and civil law codes. ${ }^{6}$ Initially, the proposed codes were to apply to all Habsburg lands and provinces, but Hungary and Lombardy were soon excluded from the effort for 
practical reasons. ${ }^{7}$ Each of the Theresian drafts dealt somewhat differently with the illegitimate.

The first draft, the so-called Codex Theresianus, was about to be published when it ran headfirst into a new governmental body created in the meantime - the State Council (Staatsrat), whose members' philosophies were often diametrically opposed to those of the codification commission. The State Council's assigned task was to review and advise on all matters submitted to the ruler - including the Codex Theresianus. Heavily influenced by natural law doctrine and German common law, the Councillors convinced the Empress that the proposed Codex contained far too much Roman law and that it was far too wordy since it tried to be both a legal textbook and a compilation of statutes. Persuaded, Maria Theresa withdrew the Codex in 1769 and ordered that it be rewritten. ${ }^{8}$ This time the drafting would be divided among three bodies - the codification commission, State Council and another new body, the Oberste Justizstelle (a combination Ministry of Justice and Supreme Court).

The redrafting began in August 1772, and Joseph II (now co-ruler with his mother) became deeply involved in the process. The increased number of participants, the numerous mandates and conflicting opinions, the differing temperaments and philosophies, all meant that the revision would be neither rapid nor smooth. It was still incomplete in 1780 when Maria Theresa died and Joseph became sole ruler. The work done during the Empress's reign proved extremely useful for her son's Code; but despite the Theresian foundation, Joseph's work was more innovative and far reaching and therefore at times quite disruptive.

Ill-suited by temperament to tolerate endless disputes and haggling, Joseph was determined that a code would appear. He cut through disputes and knotty issues to solve problems; and, most important, he took the proffered advice that parts of the code be issued as they were completed rather than waiting for the full code. And legislation did begin to appear: the Marriage Patent on 13 January 1783, the Inheritance Patent on 11 May 1786, and Part One of the Civil Code on 1 November 1786.

A brief look at the 1786 Inheritance Patent, which preceded the Code itself by six months, is instructive in the kind of leveling or equalizing of which Joseph was capable. The Patent applied equally to both sexes and to all Estates - noblility through peasants - in establishing the disposition of freely inherited property. Property was now to be divided equally among all children; and daughters could no longer be forced to renounce their right to a portion of the family wealth when they married; they would now keep both ownership and control even after their nuptials. ${ }^{9}$ 
The legal position of the illegitimate was just as substantially altered when on 24 July 1783 Joseph ordered that the stigma of illegitimacy, established in law for centuries, be entirely removed. Henceforth such persons could enter public service, become guild members, and pursue any occupation they chose. ${ }^{10}$

In guiding the new laws on legitimacy and illegitimacy, Joseph was influenced by several members of his mother's codification commission - those who belonged to the so-called Enlightenment Party. One commission member wanted to grant illegitimate children exactly the same rights as legitimate, arguing that a child had no control over the conditions under which it entered the world and therefore should not be held responsible for them. Another member of the commission stated somewhat more moderately that one could grant illegitimate children in general the rights of relatives and the inheritance rights derived from them. ${ }^{11}$

Joseph II's General Civil Law Code, Part I, was published on 1 November 1786, to take effect January $1,1787 .{ }^{12}$ In Chapter 4 , 'On the Rights between Parents and Children,' Joseph carefully defined various categories of illegitimacy, and, contrary to the conventional wisdom of the literature, not all children born out of wedlock or in an 'untimely' fashion received the same rights.

Section 1 defined legitimacy in a manner fairly standard for the time: Any child born in the seventh month after the marriage, or in the tenth month after the father's death or at any time in between was to be considered legitimate. In subsequent sections, however, the code made it extremely difficult to challenge the legitimacy of a child born during a valid marriage.

Only the husband had the right to raise questions about a child's legitimacy; and he could do so only if he proved that he had been absent for an entire year before the birth and that the mother had actually committed adultery (section 2). Since he had been away for a year, gathering proof of adultery beyond the presence of an infant would prove extremely difficult. Clearly Joseph was making it extremely difficult to withhold the right of the legitimately born from a child born within a marital union. This and other provisions expanding the rights of the illegitimate meant that even more children would be included when the inheritance was divided among the heirs, male or female, a provision that affected the nobility and the wealthiest of the middle class the most.

Joseph's most controversial provisions on the illegitimate appear in Sections 10-17 of the 4th Chapter. Section 10 extended to illegitimate children - even those born from forbidden unions - the same right to support, care, nourishment, and education guaranteed to legitimate 
children. That support was the duty primarily of the father, and paternity was to be determined according to the following guidelines.

If, at any time during the pregnancy or birth, or after, a man gave the slightest indication that he viewed the child as his own, then he had to support that child. If the father did not identify himself in any way, said the Code, the mother was 'entitled to sue for child support the man who either has admitted or can be proved to have had coitus with her during the first three months of the pregnancy' (section 10). The support was to be appropriate to the mother's Estate or station. The acknowledged father could also take the child into his own household if he wished. If the mother could not identify the father, then she was responsible for supporting the child. If both father and mother died, their heirs were responsible for supporting the illegitimate child until he could take care of himself (sections 11-14).

The really revolutionary provisions were in sections 15 to 17 . Here Joseph drew a distinction between the 'truly illegitimate' and other irregularly born children. The 'truly illegitimate' were those whose parents could not marry, that is, the child had at least one parent married to a third person at the time of conception or was born to parents for which an unremovable obstacle to marriage existed at the time of conception or birth. These children were truly illegitimate and their rights were limited to appropriate support only.

But not all illegitimately born were 'truly illegitimate.' Section 16, the most radical of Joseph's provisions, dealt with those children conceived outside of marriage by two unmarried persons where no obstacle to marriage existed or where the obstacle was removable. Here Joseph was about to cause a huge uproar: he placed these children 'equal to legitimate children' and 'participatory in all hereditary privileges on the paternal and maternal side which belong to the legitimately born children.' This section did not legitimize these children, and it did not apply if one of the parents had married a third party in the meantime.

Understandably, the legislation evoked numerous requests for clarification from various parts of the government. On 16 February $1787-$ about six weeks after his Civil Code took effect - Joseph decreed that those children referred to in the troublesome section 16 were granted not only inheritance rights equal to the legitimate toward both maternal and paternal property, but they were now clearly made 'participatory in all hereditary privileges which belong to the legitimate children....' ${ }^{13}$

On 12 April 1787 Joseph again clarified Section 16 on children born out of wedlock: 'to such a child at birth shall belong the father's name, but not his nobility or coat of arms; that such a child could demand from the mother, the father and from their parents' in a manner appropriate 
to the mother's Estate 'education, support, and representation in the same manner as legitimate children. ${ }^{14}$

Joseph's intentions in legislating for illegitimate children clearly included the goal of treating them at least equitably if not completely equally. It would also appear that this ruler intended to make men responsible - to the extent possible - for the children they begat, whether inside or outside of marriage. But there is another principle at work as well - one that appears more clearly in his provisions for adopted children.

In order to adopt a child, one had to have the agreement of the father, or if he was dead of the child's guardian, and of the guardianship authorities. The adoptive father had the responsiblity to educate, protect, support and represent the adopted child 'as if it were his natural child.' If the adopted child had his own property, the adoptive father was to administer that property and account for it during the child's minority, as any other guardian would. But the adoptive father could not simply leave his own property, or a part of it, to the adopted child. His biological children had first claim to his estate; the adopted child only to a dowry or the so-called 'obligatory share' (Pflichteil) allotted to all children. On the other hand, the adopted child retained all the rights of a blood relative toward his own biological family. ${ }^{15}$

The same principle appears in Joseph's introduction of ascendant inheritance: if there were no children then one's property went to one's parents or their children, then to grandparents and their children, etc., back to the sixth generation. Only then, if their were no ascendant or descendant (blood) relatives, did the widow inherit. ${ }^{16}$ Ascendent inheritance placed a sometimes distant blood relationship above a much closer legal one such as marriage or adoption. Among those motives that entered into Joseph II's Inheritance Patent and Civil Law Code, the continuing importance of blood relationships must certainly be included.

Joseph died in February 1790 and was succeeded by another of that century's enlightened rulers, his brother Leopold II. However, Leopold was a much more practical politician than Joseph; and faced with continuing opposition from the clergy and the nobility, he repealed Sections 10-17 of Chapter 4 of Joseph's Code along with several other subsequent explanatory decrees, and put many of the illegitimate child's rights where they had been before - with little or no claim on the father except for support, where he could be identified. But as in other of his strategies, Leopold repealed only what he had to or wanted to, and as a result most of the more enlightened provisions in Joseph's statutes remained. There was no longer any official or legal stigma attached to illegitimate birth, and Leopold in many cases simply restated, with 
slight changes, many of the provisions he repealed. The father still had primary responsiblity to support a child according to the position or Estate of its mother. However, illegitimate children could claim the family name only of the mother, yet not her coat of arms or noble rank, if she had one. Those born from forbidden union also lost their claim to the mother's property. ${ }^{17}$

In the the full 1811 Austrian General Civil Code, Francis II essentially retained the position of the illegitimate as it appeared with the Leopoldian amendments. These people could now lead full lives, have protection of the laws, enter professions, have families, and leave their property to their own legitimate children or relatives - rights first given them by Joseph II.

\section{MIRIAM J. LEVY \\ University of Hartford}

\section{Notes}

1 Gunter Wesener, 'Die Rechtsstellung des Unehelichen Kindes in Österreich (vom Mittelalter bis zur Gegenwart),' in Recueils de la Société Jean Bodin pour l'Histoire comparative des Institutions; vol. 36: L'Enfant: Europe medievale et moderne (Brussels, 1976), pp. 494-95.

2 Ibid., p. 497.

3 Ibid, pp. 498-99.

4 Ibid., pp. 500-501.

5 Ibid., p. 503.

6 See Philipp Harras von Harrasowsky, Geschichte der Codification des österreichischen Civilrechtes (Frankfurt am Main: Verlag Sauer \& Auvermann, 1968).

7 The Austrian Netherlands were administered separately, and then lost during the French Revolution. The first part of Galicia was not acquired until 1772 and the remainder in 1795; that land received its own codes in 1796-97, and then came under the general code issued in 1811.

8 See Hans Voltelini, 'Der Codex Theresianus im österreichischen Staatsrat,' Festschrift zur Jahrhundertfeier des Allgemeinen Bürgerlichen Gesetzbuches - 1.Jun1 1911 (Vienna: Manz, 1911), first part, pp. 35-82.

9 Gesetze und Verordnungen in Justizfache für die deutschen Staaten der Österreichischen Monarchie (1780-1848) (places of publication and publishers vary, 1780-1854), Joseph's Laws, \#548 and \#606. This collection is hereafter referred to as Justiz.

10 Justiz, Joseph's laws, \#161.

11 See Wesener, 'Die Rechtsstellung,' pp. 504-505.

12 Justiz, Joseph's Laws, \#591. 
13 Justiz, Joseph's Laws, \#630.

14 Justiz, Joseph's Laws, \#661.

15 Justiz, Joseph's Laws, \#591, Chapter 4, sections 27-32.

16 Justiz, Joseph's Laws, \#548, Inheritance Patent.

17 Justiz, Leopold's Laws, \#115, section 4. 